\title{
The Effect of Cellular Coenzyme $Q_{10}$ Deficiency on Lysosomal Acidification
}

\author{
Robert A. Heaton ${ }^{1, *}$, Simon Heales ${ }^{2,3,4}{ }^{\oplus}$, Khalid Rahman ${ }^{1}\left(\mathbb{D}\right.$, Darren W. Sexton ${ }^{1}(\mathbb{D}$ and \\ Iain Hargreaves 1 \\ 1 School of Pharmacy, Liverpool John Moore University, Byrom Street, Liverpool L3 3AF, UK; \\ k.rahman@ljmu.ac.uk (K.R.); D.W.Sexton@ljmu.ac.uk (D.W.S.); I.P.Hargreaves@ljmu.ac.uk (I.H.) \\ 2 Neurometabolic Unit, National Hospital, Queen Square, London WC1N 3BG, UK; \\ Simon.Heales@gosh.nhs.uk \\ 3 Enzyme Unit, Chemical Pathology, NIHR BRC Great Ormond Street Hospital, Foundation Trust, \\ London WC1N 3JH, UK \\ 4 NIHR BRC and UCL Great Ormond Street Institute of Child Health, London WC1N 1EH, UK \\ * Correspondence: r.heaton@2013.ljmu.ac.uk
}

Received: 29 May 2020; Accepted: 16 June 2020; Published: 19 June 2020

\begin{abstract}
Coenzyme $\mathrm{Q}_{10}\left(\mathrm{CoQ}_{10}\right)$ deficiency currently represents the only treatable mitochondrial disorder, however, little is known about how it may affect other organelles. The lysosome has been found to have a large concentration of $\mathrm{CoQ}_{10}$ localised at its membrane; additionally, it has been suggested that it plays a role in the normal acidification of the lysosomal lumen. As a result, in this study we assessed the effect of $\mathrm{CoQ}_{10}$ deficiency on lysosomal acidification. In order to investigate this, a neuronal cell model of $\mathrm{CoQ}_{10}$ deficiency was established via the treatment of SH-SY5Y cells with para-aminobenzoic acid (PABA). This method works through the competitive inhibition of the $\mathrm{CoQ}_{10}$ biosynthetic pathway enzyme, $\mathrm{CoQ}_{2}$. A single $1 \mathrm{mM}$ (5 days) treatment with PABA resulted in a decrease of up to $58 \%$ in cellular $\operatorname{CoQ}_{10}(p<0.05)$. It was found that this resulted in a significant decrease in fluorescence of both the LysoSensor (23\%) and LysoTracker (35\%) probes used to measure lysosomal $\mathrm{pH}(p<0.05)$. It was found that subsequent treatment with $\operatorname{CoQ}_{10}(5 \mu \mathrm{M}$, 3 days) was able to restore cellular $\mathrm{CoQ}_{10}$ concentration $(p<0.005)$, which was associated with an increase in fluorescence from both probes to around $90 \%$ of controls $(p<0.05)$, suggesting a restoration of lysosomal $\mathrm{pH}$. This study provides insights into the association between lysosomal $\mathrm{pH}$ and cellular $\mathrm{CoQ}_{10}$ status and the possibility that a deficit in the status of this isoprenoid may result in an impairment of lysosomal acidification.
\end{abstract}

Keywords: coenzyme $\mathrm{Q}_{10}$; lysosome; mitochondrial; organelles; competitive inhibition; lysosomal pH

\section{Introduction}

Coenzyme $\mathrm{Q}_{10}\left(\mathrm{CoQ}_{10}\right)$ is a lipid-soluble vitamin-like molecule synthesised in the mitochondria where it plays a vital role in the mitochondrial electron transport chain (METC), passing electrons derived from both complex I (NADH ubiquinone oxidoreductase; EC 1.6.5.3) and II (succinate ubiquinone reductase; EC 1.3.5.1) to complex III (ubiquinol cytochrome c reductase; EC 1.10.2.2) allowing a continuous passage of electrons within the chain which is required for the process of oxidative phosphorylation and the concomitant production of ATP [1]. Additionally, CoQ 10 functions as an important lipid soluble antioxidant within cellular membranes and lipoproteins, protecting them from free radical-induced oxidative damage [2].

A primary $\mathrm{CoQ}_{10}$ deficiency, which results from a genetic defect in the $\mathrm{CoQ}_{10}$ biosynthetic pathway, currently represents the only treatable METC disorder, and can have quite a heterogeneous clinical 
presentation which can be divided into five major phenotypes: encephalomyopathy, severe infantile multisystemic disease, nephropathy, cerebellar ataxia, and isolated myopathy [3]. Lowered tissue levels of $\mathrm{CoQ}_{10}$ have also been reported as a secondary consequence of disease pathophysiology, as well as drug therapy, and are known as secondary $\mathrm{CoQ}_{10}$ deficiencies [4]. $\mathrm{CoQ}_{10}$ supplementation has also shown some therapeutic potential in the treatment of a number of diseases, including mitochondrial disease [5], cardiovascular disease [6-8] and endothelial dysfunction [9]. The clinical benefit elicited by $\mathrm{CoQ}_{10}$ in the treatment of these disorders possibly relies on the ability of $\mathrm{Q}_{10}$ to restore electron flow in the METC as well as its cellular antioxidant capacity [10]. In this context, the preponderance of current studies assessing $\mathrm{CoQ}_{10}$ 's therapeutic value have focused on its effects in the METC and, thus, on diseases linked to mitochondrial dysfunction [11-13]. However, in addition to its important electron carrier role in the METC, CoQ10 has also been reported to be present in the lysosomal membrane in high concentrations [2,14], where it is has been suggested to play an important role in the tentative electron transport chain of this organelle (lysosomal electron transport chain (LETC)) [14] (Figure 1).

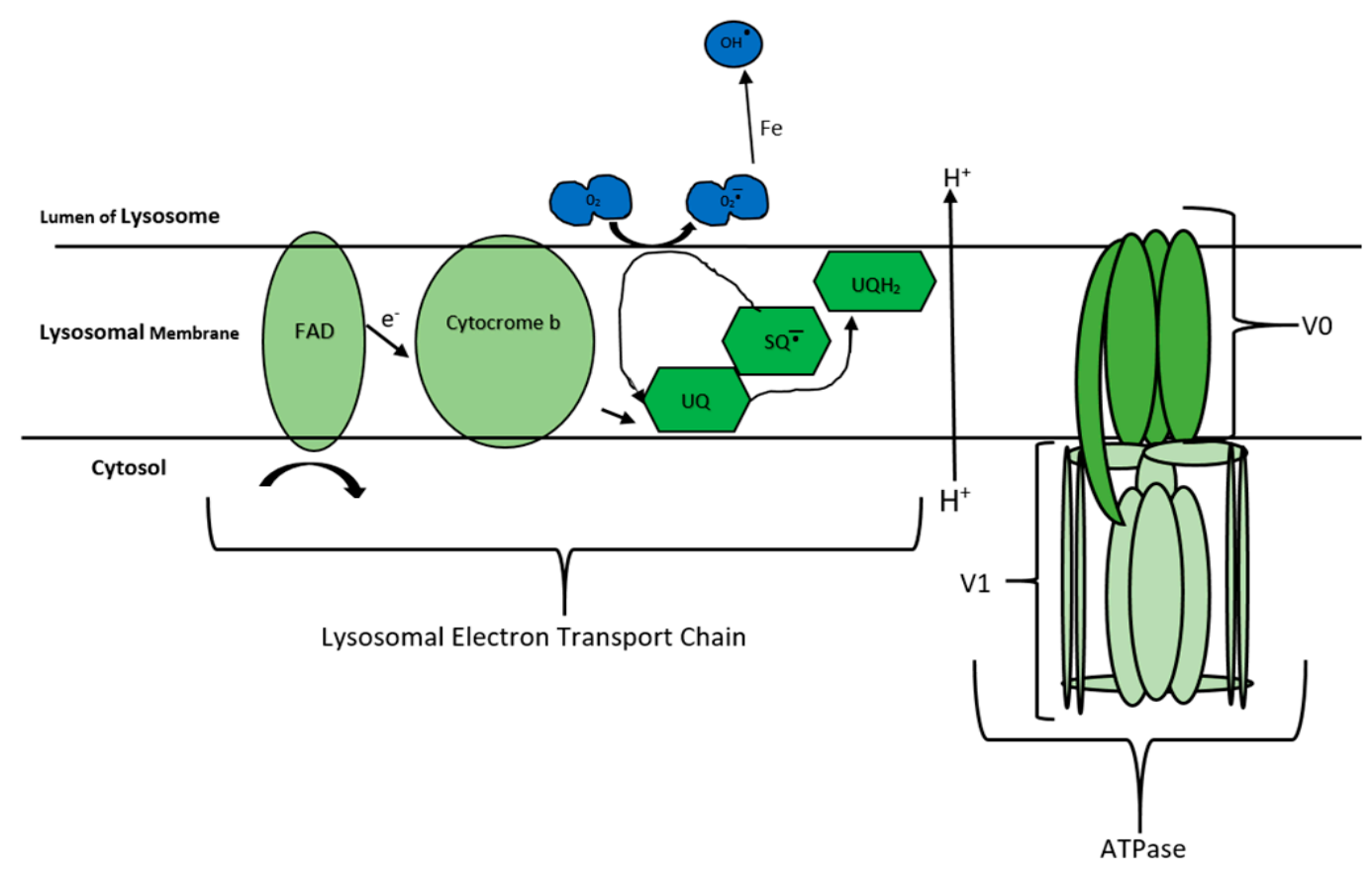

Figure 1. The lysosomal electron transport chain (LETC), adapted from Gille and Nohl [14]. The figure indicates how coenzyme $\mathrm{Q}_{10}\left(\mathrm{CoQ}_{10}\right)$ oxidation and reduction are utilised by the lysosome to move $\mathrm{H}^{+}$ into the lumen. As eluded to by Gille and Nohl [14]. The oxidation of cytoplasmic nicotinamide adenine dinucleotide (NAD) to $\mathrm{NADH}^{+}$by the flavin-adeine dinucleotide (FAD) present in the lysosomal membrane, leads to the single electron transfer to cytochrome $b$. Additionally, it has been reported that the oxidation of cytochrome $b$ was found to be proportional to the amount of ubiquinone (UQ) present in the lysosomal membrane. Ubiquinone structure allows for the transfer of two electrons leading to the production of either partially reduced ubisemiqinone or the fully reduced ubiquinol. $\mathrm{CoQ}_{10}$ 's structure then allows it to pass freely into the lysosomal lumen, transferring the electrons via molecular oxygen. The basic structure of the lysosomal ATPase is also outlined and is adapted from the paper by Zoncu, et al. [15]. The structure and function of this ATPase is similar to that found in the mitochondria, although it is involved in the hydrolysis of ATP rather than the synthesis of this molecule. It consists of 13 subunits and is divided into 2 domains, V0 and V1. The V0 domain is involved in translocating protons $\left(\mathrm{H}^{+}\right)^{\prime}$ s across the lysosomal membrane and into the lumen. The V1 domain is involved in the hydrolysis of ATP which provides the energy for the translocation of $\mathrm{H}^{+}$ ions against the $\mathrm{H}^{+}$concentration gradient for transport into the lumen. $[15,16]$. Abbreviations: FAD, flavin-adeine dinucleotide; $\mathrm{UQ}$, ubiquinone; SQ, semiquinone. 
The lysosome can be considered to be a vital organelle for cell survival, in that it has an active role in a multitude of cellular homeostatic pathways [17]. They are membrane bound organelles responsible, via enzymatic digestion, for the recycling of complex molecules and organelles such as mitochondria [18-20]. Lysosomes contain over 70 different hydrolytic enzymes that break down and digest a plethora of different cellular products such as proteins, DNA, RNA, polysaccharides and lipids $[21,22]$. Changes in lysosomal function have been linked to over 30 different diseases known as lysosomal storage diseases (LSD) [23].

The majority of lysosomal enzymes are acidic hydrolyses requiring an acidic environment for optimum activity. Thus, the lysosomal lumen $\mathrm{pH}$ is intrinsically linked to its functionality [24,25]. When compared to the relatively neutral $\mathrm{pH}$ of the cytosol (7.2), it is clear that the lysosome must have a mechanism for the movement of $\mathrm{H}^{+}$ions into the lumen against the concentration gradient. The lysosomal electron transport chain, LETC, was first observed by Gille and Nohl [14]. This is not dissimilar to the electron transport chain found in the mitochondria (METC) and could explain the presence of $\mathrm{CoQ}_{10}$ in the lysosomal membrane (Figure 1) [26-30]. As shown in Figure 1, CoQ 10 is utilised in the LETC for its oxidation/reduction abilities. Gille and Nohl [14] noted that electrons are passed from Cytocrome $b$, onto ubiquinone (UQ), reducing to ubisemiquinone ( $\mathrm{SQ}^{-}$), then an $\mathrm{O}_{2}$ molecule inside the lumen acts as a final acceptor, oxidising $\mathrm{SQ}^{-}$and moving $\mathrm{H}^{+}$ions into the lysosome. Thus, it is not unreasonable to assume that a $\mathrm{CoQ}_{10}$ deficiency may result in an impairment of lysosomal activity as the result of a deacidification of the organelle. However, as yet, it is uncertain whether CoQ10 plays a fundamental role in maintaining lysosomal $\mathrm{pH}$ and this requires confirmation.

In view of the multi-organ presentation of lysosomal disorders [31], lysosomal dysfunction may be an important factor to consider in diseases associated with a $\mathrm{CoQ}_{10}$ deficiency. At present, however, no studies have assessed the effect of a $\mathrm{CoQ}_{10}$ deficiency on lysosomal acidification which may have important clinical and therapeutic consequences. Therefore, the aim of the present study was to assess the effect of a pharmacologically-induced $\mathrm{CoQ}_{10}$ deficiency on lysosomal acidification and, subsequently, whether $\mathrm{CoQ}_{10}$ supplementation can be used to reverse this effect. The results of this study will provide important information about the role of CoQ10 in maintaining lysosomal acidification.

\section{Materials and Methods}

\subsection{Cell Culture}

All experiments were carried out using the SH-SY5Y neuroblastoma cell line provided by the UCL Great Ormond Street of Child Health, London. The effect of $\mathrm{CoQ}_{10}$ deficiency was of interest in these cells specifically in light of $\mathrm{CoQ}_{10}$ 's link to neurological disorders [32]. Prior to treatments, all cells were grown in Dulbecco's Modified Eagle's medium-high glucose in T75 cell culture flasks. Cells were passaged at $70-80 \%$ confluent, with passage number kept within $18-25$ in order to obtain reproducible results, as per standard set out by previous studies [33]. All fluorescent based assays were carried out in black flat bottomed 96-well plates, unless otherwise stated. Additionally, all cells grown for $\mathrm{CoQ}_{10}$ analysis were cultured in T75 cell culture flasks. All reagents were purchased from Sigma-Aldrich, unless stated. Both the LysoSensor and LysoTracker were purchased from Thermo Fisher scientific.

Cells were treated with a single dose of $1 \mathrm{mM}$ para-aminobenzoic acid (PABA) for 5 days following the methods previously outlined by Duberley, et al. [34]. Once seeded in wells or T75 cells were allowed to rest for $10 \mathrm{~min}$ before the addition of PABA media. The $1 \mathrm{mM}$ PABA media was made on the day and kept at $37^{\circ} \mathrm{C}$ for at least 20 min before application to the cells. PABA works through the competitive inhibition of $\mathrm{CoQ}_{10}$ biosynthesis and competes with para-hydroxybenzonate for the active site of polyprenyl-4-hydroxybenzoate transferase [35].

\section{2. $\operatorname{CoQ}_{10}$ Quantification}

The $\mathrm{CoQ}_{10}$ concentration of all neuronal cell samples in this study was determined using reverse-phase HPLC with UV detection at $275 \mathrm{~nm}$, following the method previously described by Duncan, et al. [36]. A hexane: Ethanol (5:2) solution was used to extract the $\mathrm{CoQ}_{10}$ from the cells, 
following the method previously described by Duberley, Abramov, Chalasani, Heales, Rahman and Hargreaves [34]. Once extracted, $\mathrm{CoQ}_{10}$ was resuspended in HPLC grade ethanol, and separation and quantification was achieved using a reverse phase c18 column (Phenomenex, Torrance, CA, USA) using a mobile phase comprised of methanol, ethanol and perchloric acid (700:300:1.2) at a flow rate of $0.7 \mathrm{~mL} / \mathrm{min}$. CoQ 10 detection was achieved using a Agilent 1200 series UV detector at $275 \mathrm{~nm}$ and its concentration was calculated through comparison with standard $\mathrm{CoQ}_{10}$ solution.

\subsection{Total Protein Analysis}

Cellular protein concentration was determined using the detergent compatible protein assay (DC protein assay) kit available from BIO RAD which is a modified version of the Lowry, et al. [37]. The cellular protein concentration was standardised against bovine serum (BSA) standards 0 to $200 \mu \mathrm{g} / \mathrm{mL}$. Cell samples and BSA standards $(200 \mu \mathrm{L})$ in Eppendorf tubes $(1.5 \mathrm{~mL})$ were treated with protein assay reagent $A(100 \mathrm{~mL})$ and protein assay reagent $B(800 \mathrm{~mL})$, vortex-mixed and incubated at room temperature for $25 \mathrm{~min}$. Following the incubation period, the absorbance of these samples was measured at $750 \mathrm{~nm}$ using a spectrophotometer (NorthStar Scientific, Leeds, UK, Uvikon xs).

\section{4. $\mathrm{Co}_{10}$ Treatment}

Following PABA treatments, cells were treated with $\mathrm{CoQ}_{10}$, in order to evaluate the effect of the restoration of $\mathrm{CoQ}_{10}$. $\mathrm{CoQ}_{10}$ was solubilised in ethanol and then incubated with media at $37^{\circ} \mathrm{C}$ for $15 \mathrm{~min}$ prior to addition to the SH-SY5Y cells. The concentration of $\mathrm{CoQ}_{10}$ in the media was confirmed by HPLC analysis [36]. On the day of experiment a $5 \mu \mathrm{M} \mathrm{CoQ}_{10}$ solution was made up in media and kept at $37^{\circ} \mathrm{C}$ for $20 \mathrm{~min}$. Cells were treated with a $5 \mu \mathrm{M} \mathrm{CoQ}_{10}$ since this concentration of $\mathrm{CoQ}_{10}$ has been reported to elicit some biochemical efficacy in $\mathrm{CoQ}_{10}$-deficient fibroblasts in the study by Lopez et al. (2010) [29]; increasing cellular ATP status and ameliorating oxidative stress [38]. PABA media was removed and cells washed with $1 \mathrm{X}$ PBS, $\mathrm{CoQ}_{10}(5 \mu \mathrm{M})$ treatment media with fresh PABA $(1 \mathrm{mM})$ was then added ( $200 \mu \mathrm{L}$ 96-well plate, $10 \mathrm{~mL}$ T75 culture flask) and cells incubated for 3 days according to the method of Duberley, et al. [39]. Control cells were incubated for 8 days in culture with the media being refreshed after 5 days [30].

\subsection{Lysosomal $p H$ Measurements}

For the determination of lysosomal $\mathrm{pH}$ both LysoSensor blue DND-167 and LysoTracker red DND-99 were used. Both of these probes have been developed specifically to assess lysosomal $\mathrm{pH}$ [40].

\subsection{LysoTracker}

The LysoTracker (LT) probe is made up of a fluorophore linked to a weak base that is only partially protonated at a neutral $\mathrm{pH}$, thus, it can be used to measure acidic compartments such as the lysosome [41-43]. On the day of experiment a LT media was made with a final concentration of $1 \mu \mathrm{M}$ in normal cell culture media prior to staining and kept at $37^{\circ} \mathrm{C}$ in the dark until use. After PABA treatment was complete, media was removed, and cells washed twice with 1X PBS. The LT media was then added $(200 \mu \mathrm{L})$ and cells incubated for $20 \mathrm{~min}$. Once incubated the staining media was removed and cells were washed with PBS as before. Cells were then lifted from wells using trypsin $(20 \mu \mathrm{L}$, $5 \mathrm{~min}$ ). Once lifted, fresh media was added to inhibit the trypsin, and cells taken to the flow cytometer for measurement [44].

Flowcytometry was performed on an Accuri ${ }^{\mathrm{TM}} \mathrm{C} 6$ flow cytometer (BD Biosciences, San Jose, CA, USA) with a $488 \mathrm{~nm}$ laser; FL1 was 533/30 nm, FL2 585/40 nm and FL3 $670 \mathrm{~nm}$ for detection of fluorescence. The forward scatter (FSC), side scatter (SSC) and fluorescence data were obtained with logarithmic scale configuration, gating was performed as shown in supplemental data under Figure S4. 


\subsection{LysoSensor}

On the day of measurements, LysoSensor (LS) staining media was made with standard culture media, to a final solution of $1 \mu \mathrm{M}$; this media was then kept in the dark at $37^{\circ} \mathrm{C}$ until staining. As with LT, the cell media was removed, and cells washed. LS media was then added $(200 \mu \mathrm{L})$ and cells incubated for $1 \mathrm{~h}$. Following this incubation, the media was then removed, and cells washed twice with 1X PBS. Cells were then left in $100 \mu \mathrm{L}$ of fresh PBS and fluorescence measured quickly. All LS measurements were made on a Clariostar plate reader with excitation at wavelength $373 \mathrm{~nm}$ and emission detection at $425 \mathrm{~nm}$, following the method described by Ma, et al. [45], Anway, et al. [46], Altan, et al. [47], Papakrivos, et al. [48].

\subsection{PH Calibration}

$\mathrm{pH}$ calibrants were purchased from Sigma Aldrich, clear calibrants were used and each calibrant's background fluorescence was analysed before experiments; $\mathrm{pH}$ of 4.5, 5.1, 6, and 7 were used as this was deemed to be within normal physiological conditions for the lysosome [49].

For each experiment, a $\mathrm{pH}$ calibration curve was created as per the LS method. Cells were incubated $\left(37^{\circ} \mathrm{C}\right)$ in 96 -well plates in normal cell culture medium for 5 days before $\mathrm{pH}$ calibration. The media was removed, and cells washed with 1XPBS. Cells were then stained by adding $200 \mu \mathrm{L}$ of LS staining media ( $1 \mu \mathrm{M}$ LS in pre-warmed media as described above) and incubating for $1 \mathrm{~h}\left(37^{\circ} \mathrm{C}\right)$. The staining media was then removed, and cells were washed twice with $1 \mathrm{X}$ PBS. This was followed by the addition of $100 \mu \mathrm{L}$ of the selected $\mathrm{pH}$ calibrant and the cells were incubated for a further $10 \mathrm{~min}$; the fluorescence intensity was measured using a plate reader, as outlined by Ma, Ouyang, Werthmann, Thompson and Morrow [45].

\subsection{Imaging Probes}

Assessment of the uptake of the probes was carried out using the Leica DMI6000 fluorescent microscope, with the Leica LAS X software. Cells were grown on clear 6-well plates and seeded at $80,000 \mathrm{cell} / \mathrm{mL}$. PABA treatments were carried out as described above with all media volumes set at $2 \mathrm{~mL}$. After treatments cells were twice washed with 1X PBS and stained with LT and LS probes, as outlined above. Following the addition of fresh media $(2 \mathrm{~mL})$, the cells were then subjected to imaging using fluorescence microscopy.

\subsection{Statistical Analysis}

All results are expressed as mean \pm standard error of the mean (SEM), error bars represent SEM. Data was subjected to Normality testing and once appropriate parametric analyses were confirmed, ANOVAs (groups $\geq 3$ ) with Tukey's post-hoc test or Paired T tests as indicated, were used to compare data sets. An alpha value of 0.05 was considered significant. The ' $n$ ' number represents the number of individual observations. The groups compared by statistical analysis are shown in the figure legends of the results section of the manuscript. All statistical analyses were carried out using R-Studio (Version 1.2.5033). ImageJ software was used to visualise images of the probes.

\section{Results}

\subsection{PABA Treatment}

Analysis showed that cellular $\mathrm{CoQ}_{10}$ concentration was significantly decreased $(p<0.05)$ in PABA-treated cells when compared to control cells. A 5-day treatment with $1 \mathrm{mM}$ PABA induced a $58 \%$ decrease in cellular $\mathrm{CoQ}_{10}$ content (Figure 2). It was found that treatment of cells with higher concentrations of PABA did not result in a further deficiency in $\mathrm{CoQ}_{10}$ (results not shown), thus, $1 \mathrm{mM}$ PABA was used throughout this study. The effect of PABA on cell viability was also assessed and was found to have no significant effect (data not shown), this is in agreement with a previous study undertaken by Duberley, Abramov, Chalasani, Heales, Rahman and Hargreaves [34]. 


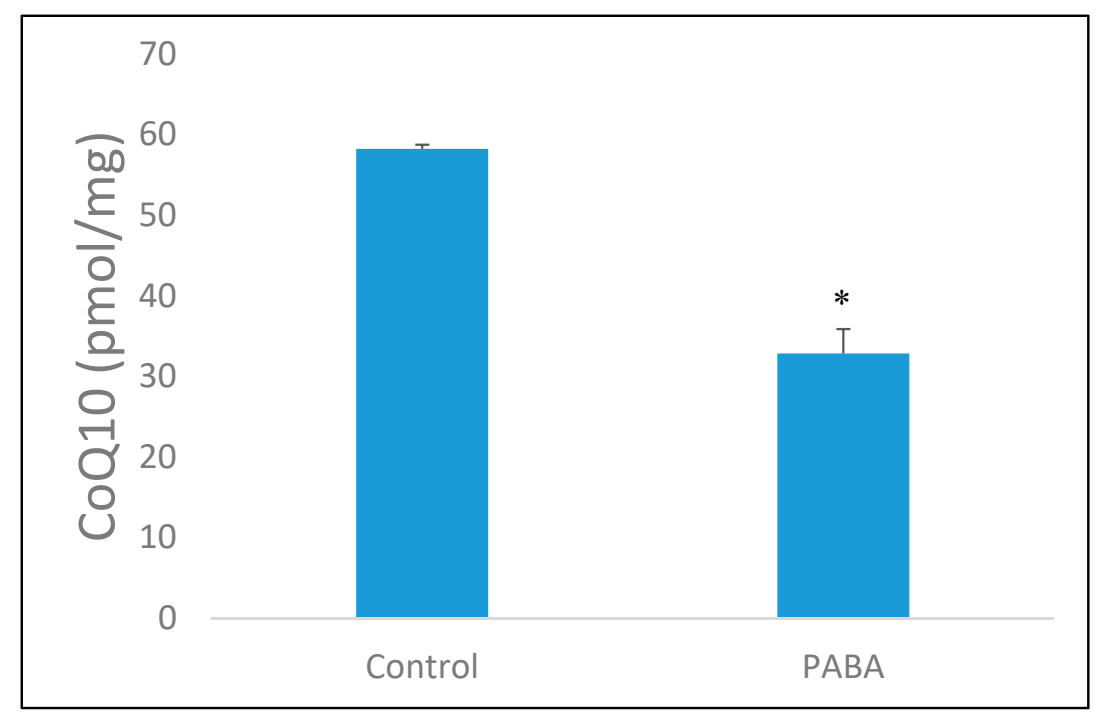

Figure 2. The endogenous $\mathrm{CoQ}_{10}$ concentration in both control and para-aminobenzoic acid (PABA)-treated ( $1 \mathrm{mM}, 5$ day) SH-SY5Y cells. CoQ 10 concentration standardised to protein baseline (mg of protein). Data available in supplemental data under Table S2. Levels of significance * $p<0.05$; $n=10$.

\section{2. $\mathrm{Co}_{10}$ Treatment}

Following PABA treatment for 5 days, media was removed, and cells incubated in media containing $5 \mu \mathrm{M} \mathrm{CoQ} 10$ and fresh PABA $(1 \mathrm{mM})$. This concentration of $\mathrm{CoQ}_{10}$ was selected since it has been reported by Lopez et al. (2010) [29] to increase cellular ATP status and ameliorate oxidative stress in $\mathrm{CoQ}_{10}$-deficient fibroblasts.

The $\mathrm{CoQ}_{10}$ status of PABA-treated cells was found to be significantly increased when compared to control cells, after a three-day incubation with $5 \mu \mathrm{M} \mathrm{CoQ} 10(p<0.005)$ (Figure 3). This result was consistent with a previous study by Duberley, Heales, Abramov, Chalasani, Land, Rahman and Hargreaves [39] where treatment resulted in an average 25-fold increase in cellular $\mathrm{CoQ}_{10}$ status (compared to $\mathrm{CoQ}_{10}$-deficient cells).

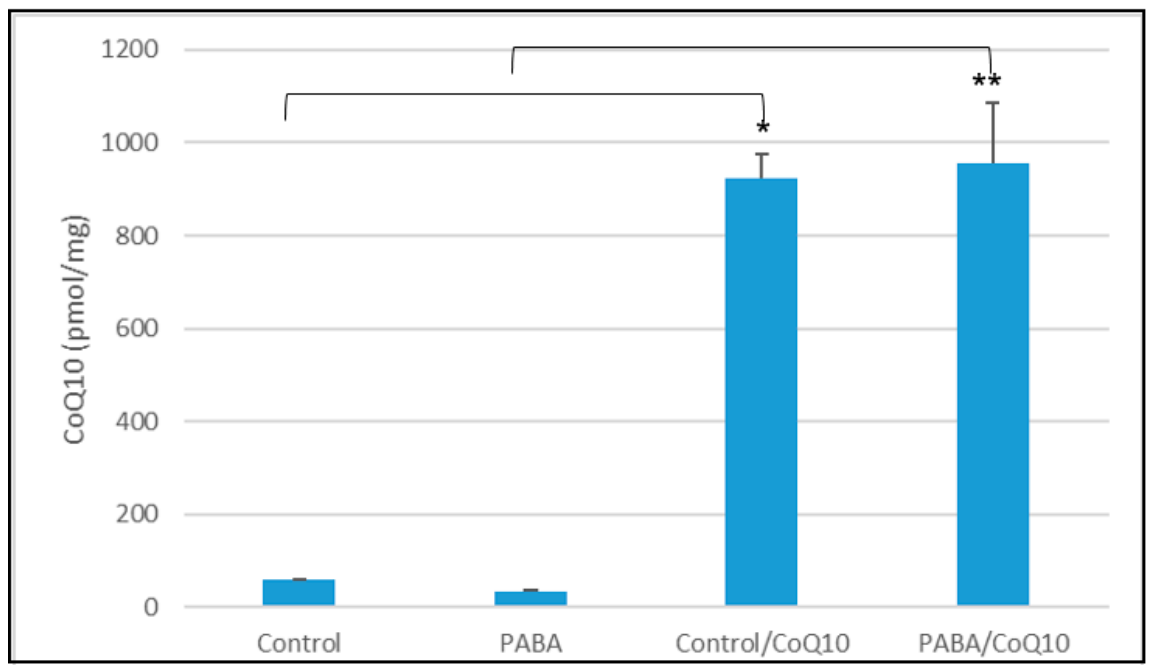

Figure 3. The cellular $\mathrm{CoQ}_{10}$ concentration, after treatment with $5 \mu \mathrm{MCoQ} 10$ over 3 days. Figure shows concentration of $\mathrm{CoQ}_{10}$ after PABA treatment and subsequent $\mathrm{CoQ}_{10}$ treatment. $\mathrm{CoQ}_{10}$ concentration standardised to protein baseline ( $\mathrm{mg}$ of protein). Comparison of groups was carried out as follows: control group vs. PABA, Control group vs. Control $\mathrm{CoQ}_{10}$ treated, PABA group vs. PABA CoQ 10 treated. Data available in supplemental data under Table S3. Level of significance ${ }^{*} p<0.05,{ }^{* *} p<0.05$; $n=26$. 


\subsection{LysoTracker}

Analysis showed that there was a significant difference $(p<0.005)$ between the fluorescence of the non-PABA-treated cells and the $\mathrm{CoQ}_{10}$-deficient (PABA-treated) cells (Figure 4). In addition, there was a $35 \%(p<0.05)$ decrease in median fluorescence on average in $\mathrm{CoQ}_{10}$-deficient cells when compared to the control (Figure 4).

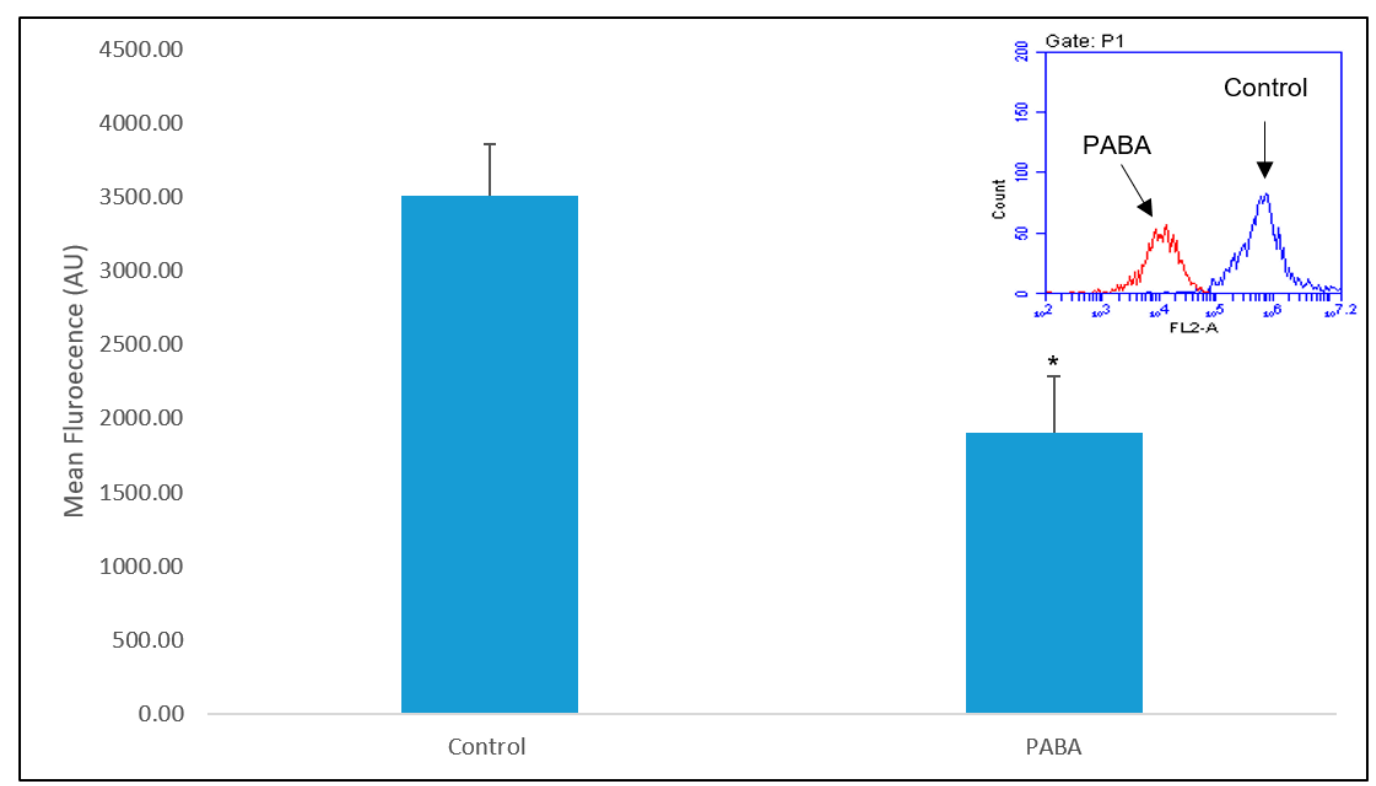

Figure 4. Shows the mean LysoTracker DND-99 fluorescence of PABA-treated cells vs. controls. Additionally, this figure shows the fluorescence shift after PABA treatment. Data available in supplemental data under Figure S4. Level of significance ${ }^{*} p<0.05 ; n=26$.

An assessment of whether PABA interferes with the LT assay was also undertaken, this was to ensure that PABA was not affecting the results. It was found that when PABA and LT were tested simultaneously no effect on the florescence of LT was evident.

\subsection{LysoSensor}

To assess the lysosomal $\mathrm{pH}$, a calibration curve was constructed to allow quantification of $\mathrm{pH}$, prior to experiments (Figure 5); fluorescence of $\mathrm{pH}$ calibrants was measured and found to be within the same range as the PBS used in experiments. Treatment with PABA (1 mM 5 days) showed a significant decrease in LS fluorescence when compared to the control $(p<0.05)$. The results show a decrease of $23 \%$ in LS fluorescence (Figure 6).

Following 5 days of treatment with PABA, cells were incubated with $\mathrm{CoQ}_{10}(5 \mu \mathrm{M}$ for 3 days) in the presence of fresh PABA (Figure 7). Analysis of this data showed that LS fluorescence was significantly increased when compared to the PABA-treated cells $(p<0.05)$, although it did not exceed $90 \%$ of the control value. Using the calibration curve, the $\mathrm{pH}$ of the neuronal cell showed a possible increased from 5.1 to 6.2 following PABA-induced diminution of $\mathrm{CoQ}_{10}$. The following $\mathrm{CoQ}_{10}$ treatment corresponded to a possible decreased in $\mathrm{pH}$ of 5.4 according to the $\mathrm{pH}$ calibration curve (Figure 5). 


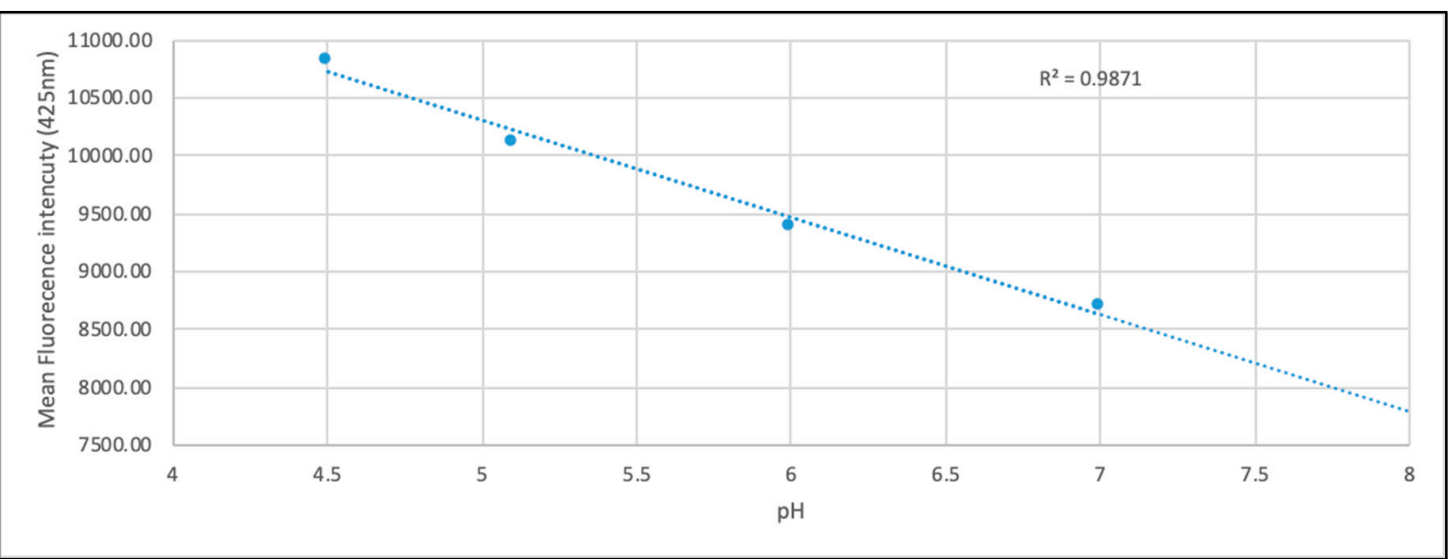

Figure 5. Standard $\mathrm{pH}$ curve from LysoSensor DND-167 after treatment of cells with standard $\mathrm{pH}$ solutions. Represents the mean fluorescence of all $\mathrm{pH}$ calibration data. $n=8$ (for each calibrant). Data available in supplemental data under Table S5.

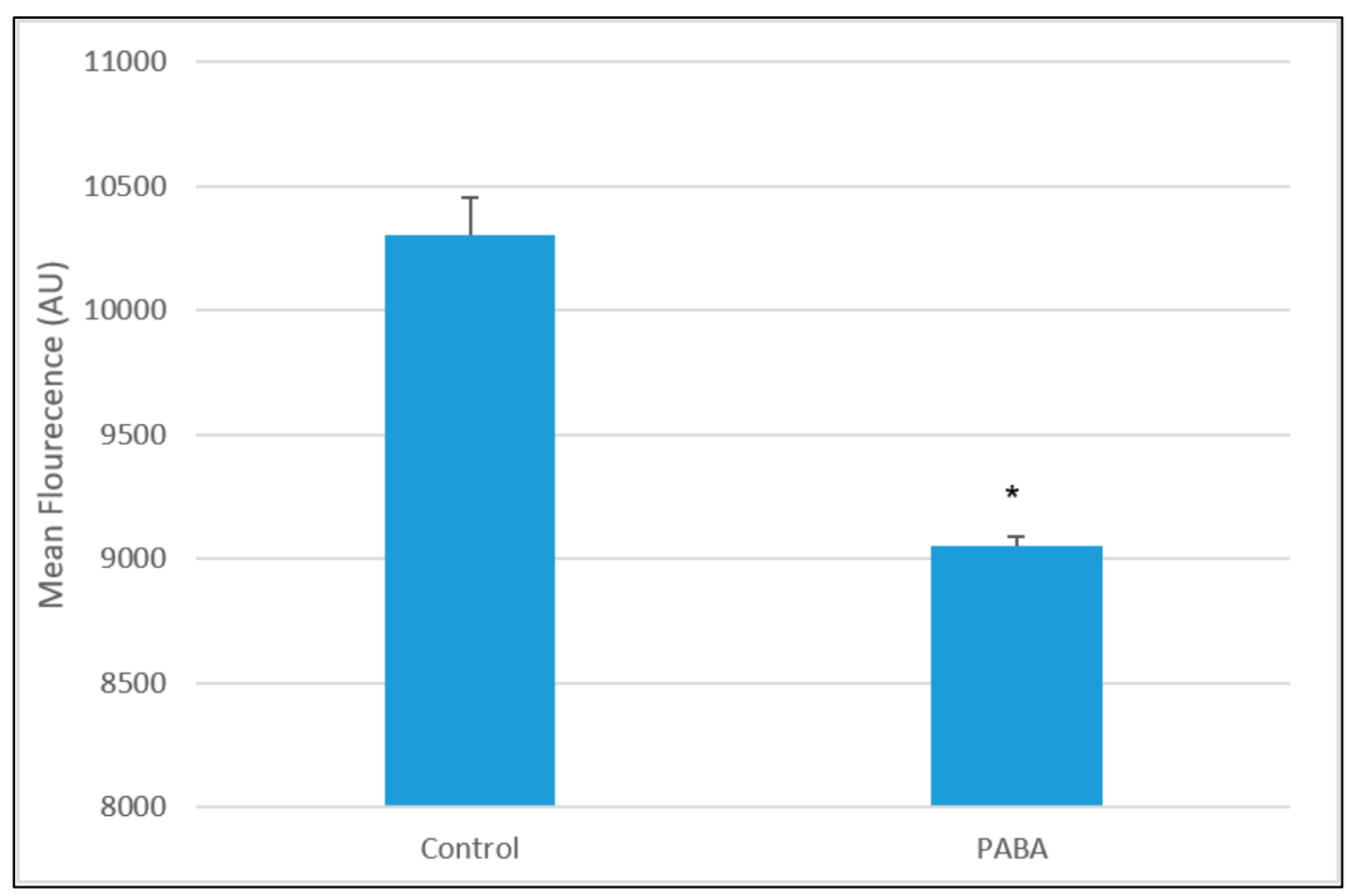

Figure 6. Mean LysoSensor fluorescence for PABA-treated cells vs. controls. Data available in supplemental data under Table S6. Significance levels * $p<0.05 ; n=94$. 


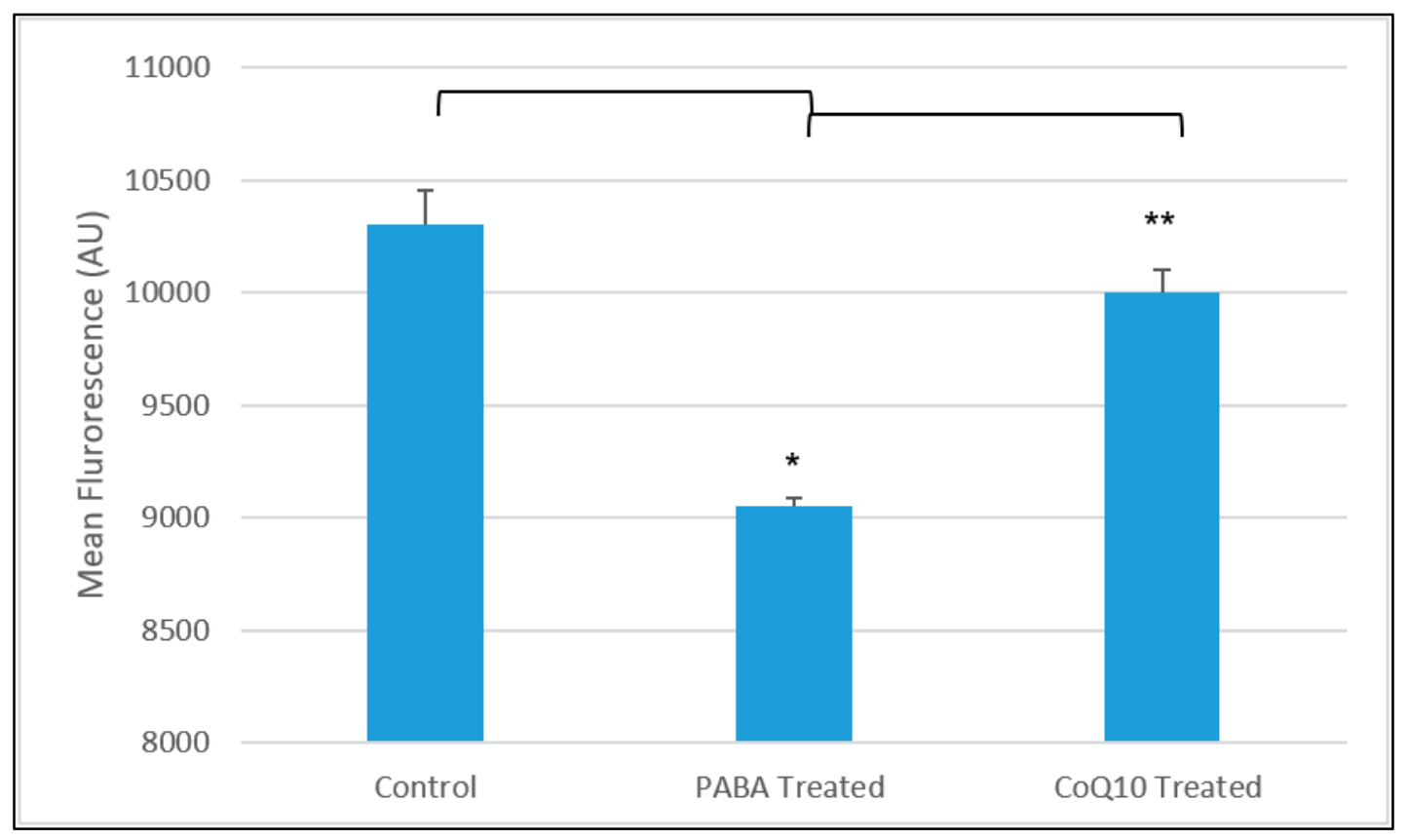

Figure 7. Mean fluorescence of control, PABA-treated cells and $\mathrm{CoQ}_{10}(5 \mu \mathrm{M})$ treated cells in the presence of PABA using data obtained in Figure 6. PABA-treated and $\mathrm{CoQ}_{10}$-treated (in the presence of PABA) cells following 3 days of incubation. Control and PABA-treated cells had been cultured for 5 days prior to this experiment as outlined in the cell culture section of the Material and Methods. Following incubation with $\mathrm{CoQ}_{10}$, the LysoSensor (LS) fluorescence is significantly increased when compared to the PABA-treated cells. Comparisons of groups was carried out as follows: Control cells vs. PABA-treated cells, control cells vs. CoQ 10 -treated cells, PABA-treated cells vs. CoQ ${ }_{10}$-treated cells. Data available in supplemental data under Table S6/7. Significance level ${ }^{*} p<0.05 ; n=94,{ }^{* *} p<0.05$, $n=94$.

\subsection{Visulisation of Probes}

To assess the uptake and localisation of the probes, fluorescent imaging of the cells was carried out. However, images of the LS blue DND-167 could not produce sufficient resolution at X40 (objective); therefore, future analysis of this probe will be required.

Analysis of the cellular distribution of the LT probe indicates that it was taken up by the cells and held in small pockets within the cell membrane (Figure 8); this would indicate that the probe was held within acidic organelles. Additionally, this shows that there was minimum fluorescence across the cell outside of these small pockets. Visualisation of control cells and PABA-treated cells suggest that the cellular distribution of the LT probe is unaffected by PABA treatment, however more data is required for confirmation. 

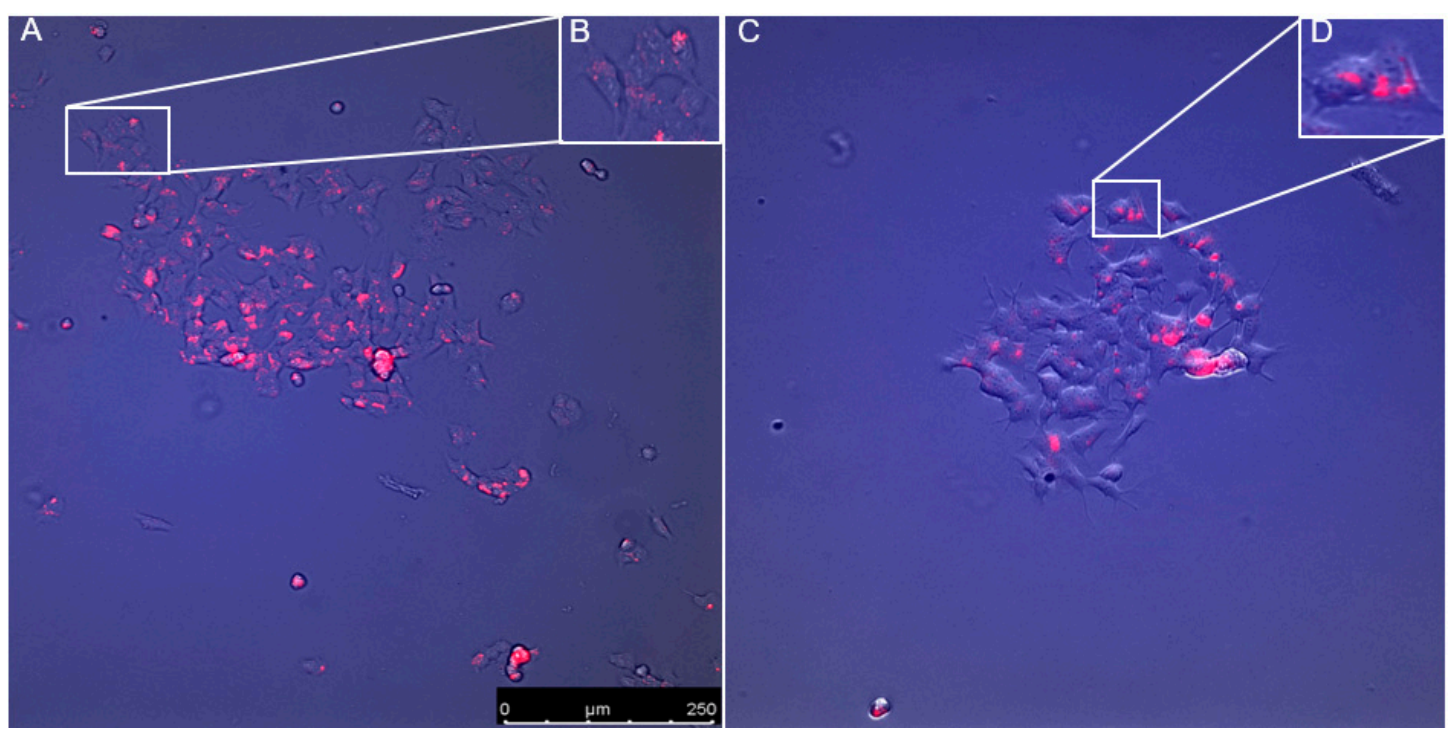

Figure 8. Distribution of the LysoTracker DND-99 probe in both control cells (A) and PABA-treated cells (B). (C) and (D) show small localisation of LysoTracker in the cells. Suggests that PABA has little to no effect on the cellular distribution of the probe. Images taken using the Leica DMI6000 fluorescent microscope, with the Leica LAS X software, at $x 40$ (objective).

\section{Discussion}

The results of this study have shown that a $50 \%$ decrease in cellular $\mathrm{CoQ}_{10}$ status can be associated with a $20 \%$ decrease in lysosomal fluorescence indicating a change in lysosomal pH (Figure 6).

Lysosomal function is imperative to cellular homeostasis, and $\mathrm{CoQ}_{10}$ could play a fundamental role in maintaining lysosomal acidification [14]. The effect of cellular $\mathrm{CoQ}_{10}$ deficiency on mitochondrial function has been investigated previously in a number of studies reported by Ben-Meir, et al. [50], Shults, et al. [51]. However, to the best of our knowledge the effect of $\mathrm{CoQ}_{10}$ deficiency on lysosomal acidification has not been reported.

Following the work of Duberley, Heales, Abramov, Chalasani, Land, Rahman and Hargreaves [39] a $\mathrm{CoQ}_{10}$-deficient neuronal cell line was established. Incubating the neuroblastoma-derived SHSY-5Y cells with $1 \mathrm{mM}$ PABA for five days, led to a decrease in cellular $\mathrm{CoQ}_{10}$ concentration ranging from 50 to $58 \%$ of the normal level. This enabled the analysis of $\mathrm{CoQ}_{10}$ deficiency on lysosomal acidification to be undertaken.

This study employed two independent fluorescent probes in order to evaluate lysosomal $\mathrm{pH}$. Firstly, the LS probe was used, incorporating a plate reader method. LS is a fluorophore designed to accumulate within acidic organelles as a result of protonation. Additionally, a result of this protonation is fluorescence quenching of the probe by its weak base side chain resulting in an increased fluorescence intensity [52]. The $\mathrm{pK}_{\mathrm{a}}$ of LS blue DND-167 is 5.1 meaning the probe is ideal for measuring low $\mathrm{pH}$ environments. In this study a set of standard $\mathrm{pH}$ controls were set up alongside each experiment, which showed that the change in fluorescence was proportional to the change in $\mathrm{pH}$ (Figure 5).

A decrease in cellular $\mathrm{CoQ}_{10}$ concentration was found to result in a significant decrease in LS fluorescence intensity when compared to control cells. To ensure that this effect was not due to PABA fluorescence or direct interaction with the probe, a number of controls were run, including empty wells and wells containing only PABA media. No significant difference was found in any control, indicating that the modulated fluorescence effects were due to a decrease in $\mathrm{CoQ}_{10}$ status. The results, shown in Figure 6, suggest that a decrease in $\mathrm{CoQ}_{10}$ concentration results in a decrease in lysosomal acidification. This study also attempted to create a standard curve for LS fluorescence intensity compared to $\mathrm{pH}$, using $\mathrm{pH}$ standard solutions. Combining the results from across all experiments gave a linear relationship between $\mathrm{pH}$ and mean fluorescence intensity (Figure 5). However, analysis of 
individual experiments gave generally non-linear results, suggesting that a more sensitive probe will be required to calculate definitive $\mathrm{pH}$ values, as day-to-day variations may compromise the results.

The results from the LT probe also show a significant decrease in fluorescence intensity after PABA treatment, when compared to the control (Figure 4). The LT probe is a member of the same family of $\mathrm{pH}$-sensitive probes as LS and deploys a similar mechanism of action [34]. Weakly-based amines selectively accumulate in low $\mathrm{pH}$ environments, where the probe is protonated, increasing its fluorescence. Previous peer-reviewed studies have successfully shown that changes in LT fluorescence can be attributed to large changes in lysosomal $\mathrm{pH}$, though more subtle changes are difficult to ascertain [43]. Where consideration of altered LT fluorescence intensity may be linked to changes in size and/or quantity of lysosome within cells, imaging was attempted to mitigate this and found little to no observable changes in LT distribution (Figure 8). Our sizeable change in LT fluorescence intensity combined with a lack of identifiable changes in LT distribution in our imaging, facilitate the most probable conclusion of change in fluorescence being attributed to change in lysosomal $\mathrm{pH}$. This is also applicable to the use of LS probes [34] and, therefore, further studies will be required to assess the lysosomal content of the neuronal cells before we can confirm or refute that the decrease in fluorescence intensity is specifically caused by a change in lysosomal $\mathrm{pH}$. With this caveat in mind however, the most probable reason for the observed changes in fluorescence, is due to changes in lysosomal $\mathrm{pH}$ inflicted by $\mathrm{CoQ}_{10}$ concentration changes.

Evaluation of the uptake and localisation of both the LT and LS probes was carried out (Figure 8) using fluorescence microscopy at $\times 40$ (objective). However, this did not have sufficient magnification to observe the LS, thus further microscopic studies will be needed to confirm the LS. The analysis of the LT probe showed it was taken up by the cells and localised in small pockets within the cytoplasm (Figure 8). Following data provided by Thermo Fishier and previous studies, it is reasonable to assume that these small pockets of fluorescence within the cell are acidic organelles such as lysosomes.

This study also evaluated the effect of $\mathrm{CoQ}_{10}$ supplementation on the $\mathrm{CoQ}_{10}$-deficient cell model (Figure 3). This was done to evaluate if the effects of $\mathrm{CoQ}_{10}$ deficiency were reversible. Assessment of $\mathrm{CoQ}_{10}$ supplementation showed a significant increase in both LS and LT fluorescence intensity when compared to PABA-treated cells (Figure 7). In view of the antioxidant function of $\mathrm{CoQ}_{10}$, a decrease in the concentration of cellular $C_{0} Q_{10}$ will cause an increase in reactive oxygen species (ROS) generation and may result in oxidative stress, as indicated in the study by Duberley, Abramov, Chalasani, Heales, Rahman and Hargreaves [34]. Interestingly, it has been reported that the lysosome itself is susceptible to oxidative stress-induced impairment [53], and, therefore, a deficit in $\mathrm{CoQ}_{10}$ status may adversely affect lysosomal acidification by impairing the activity of the LETC and/or causing oxidative damage to the organelle. However, at present it is uncertain what causes lysosomal deacidification resulting from the PABA-induced $\mathrm{CoQ}_{10}$ deficiency and this will form the basis of further work. Interestingly, supplementation with $5 \mu \mathrm{MCoQ} 10$ was not able to fully restore lysosomal $\mathrm{pH}$ to control levels. In view of the significant increase in cellular $\mathrm{CoQ}_{10}$ status (compared to control levels) of the PABA-treated neurons following treatment with $5 \mu \mathrm{M} \mathrm{CoQ} 10$ (Figure 3), it is at present uncertain whether the restoration of lysosomal $\mathrm{pH}$ may be elicited by more physiological levels of cellular $\mathrm{CoQ}_{10}$ that falls within control limits. In this regard, future studies will be undertaken to assess the effect of lower dosage $\mathrm{CoQ}_{10}$ treatments on lysosomal $\mathrm{pH}$ to determine the cellular level of $\mathrm{CoQ}_{10}$ required to restore lysosomal $\mathrm{pH}$ in the $\mathrm{CoQ}_{10}$-deficient neurons.

It is uncertain at present by what mechanism(s) the deficit in neuronal cell $\mathrm{CoQ}_{10}$ status has caused an increase in lysosomal $\mathrm{pH}$, in view of the roles ascribed to CoQ10 in both the LETC [10] and METC [4]. Importantly, the V-ATPase has a major role in maintaining lysosomal $\mathrm{pH}$ via its ability to pump protons into the lumen of the organelle [25]. However, the data shown in this study do not detract from our finding that decreased $\mathrm{CoQ}_{10}$ availability leads to a perturbation of lysosomal homeostasis. Furthermore, a diminution of $\mathrm{CoQ}_{10}$ in the lysosomal membrane may also impair the proton pumping capability of the LETC [4] which may also impact upon lysosomal $\mathrm{pH}$. Although the possibility arises that both of these mechanisms may be the cause of the deacidification of the 
lysosome following a deficit in $\mathrm{CoQ}_{10}$ status, further studies will be undertaken to confirm or refute this possibility.

In conclusion, the results from the present study indicate that a $\mathrm{CoQ}_{10}$ deficiency results in impairment of lysosomal acidification. It would be reasonable to assume that this change in $\mathrm{pH}$ would lead to a decrease in lysosomal function. This study also found that treatment with exogenous $\mathrm{Co}_{10}$ $(5 \mu \mathrm{M})$ restored the fluorescence to an average of $90 \%$ of the controls, suggesting a restoration of lysosomal $\mathrm{pH}$. This suggest that a deficit in cellular $\mathrm{CoQ}_{10}$ status may impact upon on lysosomal function as well as its widely described effect on the mitochondria. The possible mechanisms by which $\mathrm{CoQ}_{10}$ exerts its effects are shown in Figure 9, however, further work is required to elucidate the relationship between cellular $\mathrm{CoQ}_{10}$ status and lysosomal function.

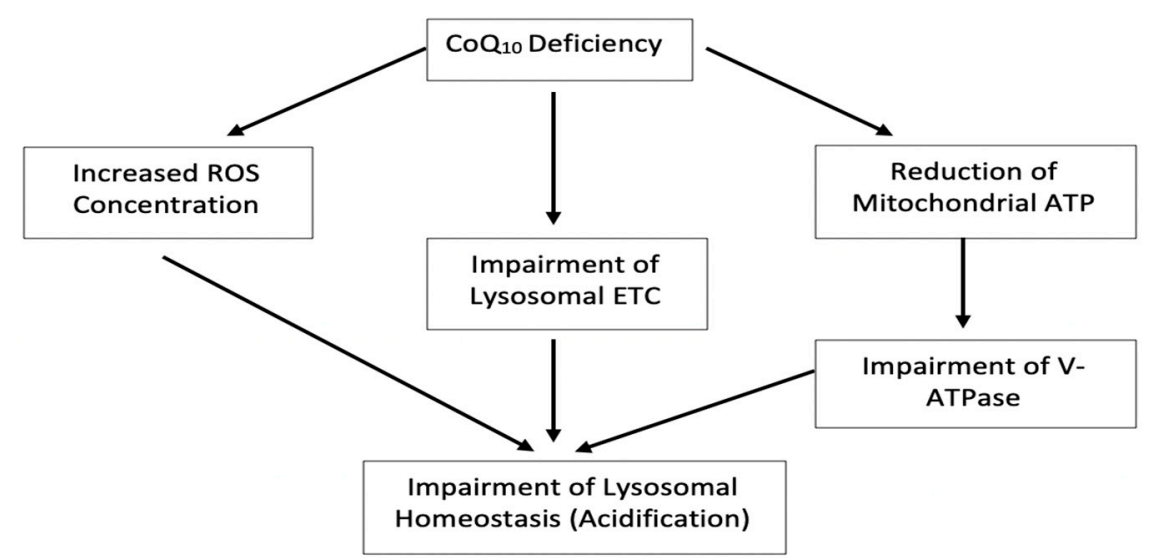

Figure 9. Tentative schematic of possible mechanisms of how $\mathrm{CoQ}_{10}$ deficiency may influence the acidification of lysosomes.

Supplementary Materials: The following are available online at http://www.mdpi.com/2077-0383/9/6/1923/s1, Table S2: Cellular $\mathrm{CoQ}_{10}$ concentration pre and post PABA treatment, Table S3: Cellular CoQ10 concentration post CoQ10 supplementation, Table S4: Cellular $\mathrm{CoQ}_{10}$ concentration post $\mathrm{CoQ}_{10}$ supplementation, Figure S4: Flow cytometry analysis of cellular LS fluorescence pre and post PABA treatment, Table S5: Mean LS fluorescence after standard pH solution exposure, Table S6/7: analysis of LS florescence during $\mathrm{CoQ}_{10}$ deficiency and supplementation.

Author Contributions: Conceptualization, I.H.; Data curation, R.A.H. and D.W.S.; Formal analysis, R.A.H.; Funding acquisition, I.H.; Investigation, R.A.H.; Methodology, R.A.H., K.R. and I.H.; Resources, S.H. and D.W.S.; Supervision, S.H., K.R., D.W.S. and I.H.; Writing—original draft, R.A.H.; Writing—review \& editing, S.H., K.R., D.W.S. and I.H. All authors have read and agreed to the published version of the manuscript.

Funding: This research received no external funding

Conflicts of Interest: The authors declare no conflict of interest

\section{References}

1. Crane, F.L. Biochemical functions of coenzyme Q10. J. Am. Coll. Nutr. 2001, 20, 591-598. [CrossRef] [PubMed]

2. Turunen, M.; Olsson, J.; Dallner, G. Metabolism and function of coenzyme Q. Biochim. Biophys. Acta (BBA) Biomembr. 2004, 1660, 171-199. [CrossRef] [PubMed]

3. Yubero, D.; Montero, R.; Artuch, R.; Land, J.M.; Heales, S.J.; Hargreaves, I.P. Biochemical diagnosis of coenzyme q10 deficiency. Mol. Syndromol. 2014, 5, 147-155. [CrossRef] [PubMed]

4. Hargreaves, I.P. Ubiquinone: Cholesterol's reclusive cousin. Ann. Clin. Biochem. 2003, 40, 207-218. [CrossRef]

5. Hargreaves, I. Coenzyme Q10 as a therapy for mitochondrial disease. Int. J. Biochem. Cell Biol. 2014, 49, 105-111. [CrossRef]

6. DiNicolantonio, J.J.; Bhutani, J.; Mccarty, M.F.; O'Keefe, J.H. Coenzyme Q10 for the treatment of heart failure: A review of the literature. Open Heart 2015, 2, 000326. [CrossRef] 
7. Mortensen, A.L.; Rosenfeldt, F.; Filipiak, K.J. Effect of coenzyme Q10 in Europeans with chronic heart failure: A sub-group analysis of the Q-SYMBIO randomized double-blind trial. Cardiol. J. 2019, 26, 147-156. [CrossRef]

8. Mortensen, S.A.; Rosenfeldt, F.; Kumar, A.; Dolliner, P.; Filipiak, K.J.; Pella, D.; Alehagen, U.; Steurer, G.; Littarru, G.P.; Q-SYMBIO Study Investigators. The effect of coenzyme Q10 on morbidity and mortality in chronic heart failure: Results from Q-SYMBIO: A randomized double-blind trial. JACC: Heart Fail. 2014, 2 , 641-649.

9. Gao, L.; Mao, Q.; Cao, J.; Wang, Y.; Zhou, X.; Fan, L. Effects of coenzyme Q10 on vascular endothelial function in humans: A meta-analysis of randomized controlled trials. Atherosclerosis 2012, 221, 311-316. [CrossRef]

10. Neergheen, V.; Chalasani, A.; Wainwright, L.; Yubero, D.; Montero, R.; Artuch, R.; Hargreaves, I. Coenzyme Q10 in the treatment of mitochondrial disease. J. Inborn Errors Metab. Screen. 2017, 5, 2326409817707771. [CrossRef]

11. Duncan, A.J.; Bitner-Glindzicz, M.; Meunier, B.; Costello, H.; Hargreaves, I.P.; López, L.C.; Hirano, M.; Quinzii, C.M.; Sadowski, M.I.; Hardy, J. A nonsense mutation in COQ9 causes autosomal-recessive neonatal-onset primary coenzyme Q10 deficiency: A potentially treatable form of mitochondrial disease. Am. J. Hum. Genet. 2009, 84, 558-566. [CrossRef] [PubMed]

12. Federico, A.; Cardaioli, E.; Da Pozzo, P.; Formichi, P.; Gallus, G.N.; Radi, E. Mitochondria, oxidative stress and neurodegeneration. J. Neurol. Sci. 2012, 322, 254-262. [CrossRef] [PubMed]

13. Rahman, S.; Hargreaves, I.; Clayton, P.; Heales, S. Neonatal presentation of coenzyme Q10 deficiency. J. Pediatrics 2001, 139, 456-458. [CrossRef] [PubMed]

14. Gille, L.; Nohl, H. The existence of a lysosomal redox chain and the role of ubiquinone. Arch. Biochem. Biophys. 2000, 375, 347-354. [CrossRef] [PubMed]

15. Zoncu, R.; Bar-Peled, L.; Efeyan, A.; Wang, S.; Sancak, Y.; Sabatini, D.M. mTORC1 senses lysosomal amino acids through an inside-out mechanism that requires the vacuolar H+-ATPase. Science 2011, 334, 678-683. [CrossRef] [PubMed]

16. Forgac, M. Structure and function of vacuolar class of ATP-driven proton pumps. Physiol. Rev. 1989, 69, 765-796. [CrossRef]

17. Weissmann, G. The role of lysosomes in inflammation and disease. Annu. Rev. Med. 1967, 18, 97-112. [CrossRef]

18. De Duve, C. The lysosome. Sci. Am. 1963, 208, 64-73. [CrossRef]

19. Smith, R.E.; Farquhar, M.G. Lysosome function in the regulation of the secretory process in cells of the anterior pituitary gland. J. Cell Biol. 1966, 31, 319-347. [CrossRef]

20. Kroemer, G.; Jäättelä, M. Lysosomes and autophagy in cell death control. Nat. Rev. Cancer 2005, 5, 886-897. [CrossRef]

21. Aronson, N.N.; de Duve, C. Digestive activity of lysosomes II. The digestion of macromolecular carbohydrates by extracts of rat liver lysosomes. J. Biol. Chem. 1968, 243, 4564-4573. [PubMed]

22. Wartosch, L.; Bright, N.A.; Luzio, J.P. Lysosomes. Curr. Biol. 2015, 25, R315-R316. [CrossRef] [PubMed]

23. Ferreira, C.R.; Gahl, W.A. Lysosomal storage diseases. Transl. Sci. Rare Dis. 2017, 2, 1-71. [CrossRef] [PubMed]

24. Mindell, J.A. Lysosomal acidification mechanisms. Annu. Rev. Physiol. 2012, 74, 69-86. [CrossRef] [PubMed]

25. Ishida, Y.; Nayak, S.; Mindell, J.A.; Grabe, M. A model of lysosomal pH regulation. J. Gen. Physiol. 2013, 141, 705-720. [CrossRef]

26. Kalen, A.; Norling, B.; Appelkvist, E.; Dallner, G. Ubiquinone biosynthesis by the microsomal fraction from rat liver. Biochim. Biophys. Acta (BBA) Gen. Subj. 1987, 926, 70-78. [CrossRef]

27. Nohl, H.; Gille, L. Lysosomal ROS formation. Redox Rep. 2005, 10, 199-205. [CrossRef]

28. Takahashi, T.; Okamoto, T.; Mori, K.; Sayo, H.; Kishi, T. Distribution of ubiquinone and ubiquinol homologues in rat tissues and subcellular fractions. Lipids 1993, 28, 803-809. [CrossRef]

29. Nohl, H.; Gille, L. The bifunctional activity of ubiquinone in lysosomal membranes. Biogerontology 2002, 3, 125-131. [CrossRef]

30. Zhang, Y.; Turunen, M.; Appelkvist, E.-L. Restricted uptake of dietary coenzyme Q is in contrast to the unrestricted uptake of $\alpha$-tocopherol into rat organs and cells. J. Nutr. 1996, 126, 2089-2097. [CrossRef]

31. Parkinson-Lawrence, E.J.; Shandala, T.; Prodoehl, M.; Plew, R.; Borlace, G.N.; Brooks, D.A. Lysosomal storage disease: Revealing lysosomal function and physiology. Physiology 2010, 25, 102-115. [CrossRef] [PubMed] 
32. Rahman, S.; Clarke, C.F.; Hirano, M. 176th ENMC International Workshop: Diagnosis and treatment of coenzyme Q10 deficiency. Neuromuscul. Disord. 2012, 22, 76. [CrossRef] [PubMed]

33. Biedler, J.L.; Roffler-Tarlov, S.; Schachner, M.; Freedman, L.S. Multiple neurotransmitter synthesis by human neuroblastoma cell lines and clones. Cancer Res. 1978, 38, 3751-3757. [PubMed]

34. Duberley, K.E.; Abramov, A.Y.; Chalasani, A.; Heales, S.J.; Rahman, S.; Hargreaves, I.P. Human neuronal coenzyme Q10 deficiency results in global loss of mitochondrial respiratory chain activity, increased mitochondrial oxidative stress and reversal of ATP synthase activity: Implications for pathogenesis and treatment. J. Inherit. Metab. Dis. Off. J. Soc. Study Inborn Errors Metab. 2013, 36, 63-73. [CrossRef] [PubMed]

35. Alam, S.S.; Nambudiri, A.; Rudney, H. 4-Hydroxybenzoate: Polyprenyl transferase and the prenylation of 4-aminobenzoate in mammalian tissues. Arch. Biochem. Biophys. 1975, 171, 183-190. [CrossRef]

36. Duncan, A.J.; Heales, S.J.; Mills, K.; Eaton, S.; Land, J.M.; Hargreaves, I.P. Determination of coenzyme Q10 status in blood mononuclear cells, skeletal muscle, and plasma by HPLC with di-propoxy-coenzyme Q10 as an internal standard. Clin. Chem. 2005, 51, 2380-2382. [CrossRef]

37. Lowry, O.H.; Rosebrough, N.J.; Farr, A.L.; Randall, R.J. Protein measurement with the Folin phenol reagent. J. Biol. Chem. 1951, 193, 265-275.

38. López, L.C.; Quinzii, C.M.; Area, E.; Naini, A.; Rahman, S.; Schuelke, M.; Salviati, L.; DiMauro, S.; Hirano, M. Treatment of CoQ10 deficient fibroblasts with ubiquinone, CoQ analogs, and vitamin C: Time-and compound-dependent effects. PLoS ONE 2010, 5, e11897. [CrossRef]

39. Duberley, K.; Heales, S.; Abramov, A.; Chalasani, A.; Land, J.; Rahman, S.; Hargreaves, I. Effect of Coenzyme Q10 supplementation on mitochondrial electron transport chain activity and mitochondrial oxidative stress in Coenzyme Q10 deficient human neuronal cells. Int. J. Biochem. Cell Biol. 2014, 50, 60-63. [CrossRef]

40. Johnson, I.D. Molecular Probes Handbook: A Guide to Fluorescent Probes and Labeling Technologies; Life Technologies Corporation: Carlsbad, CA, USA, 2010; p. 3.

41. Kang, C.-C.; Huang, W.-C.; Kouh, C.-W.; Wang, Z.-F.; Cho, C.-C.; Chang, C.-C.; Wang, C.-L.; Chang, T.-C.; Seemann, J.; Huang, L.J.-S. Chemical principles for the design of a novel fluorescent probe with high cancer-targeting selectivity and sensitivity. Integr. Biol. 2013, 5, 1217-1228. [CrossRef]

42. Avrahami, L.; Farfara, D.; Shaham-Kol, M.; Vassar, R.; Frenkel, D.; Eldar-Finkelman, H. Inhibition of Glycogen Synthase Kinase-3 Ameliorates $\beta$-Amyloid Pathology and Restores Lysosomal Acidification and Mammalian Target of Rapamycin Activity in the Alzheimer Disease Mouse Model In Vivo and In Vitro Studies. J. Biol. Chem. 2013, 288, 1295-1306. [CrossRef] [PubMed]

43. Guha, S.; Coffey, E.E.; Lu, W.; Lim, J.C.; Beckel, J.M.; Laties, A.M.; Boesze-Battaglia, K.; Mitchell, C.H. Approaches for detecting lysosomal alkalinization and impaired degradation in fresh and cultured RPE cells: Evidence for a role in retinal degenerations. Exp. Eye Res. 2014, 126, 68-76. [CrossRef] [PubMed]

44. Yamada, D.; Saiki, S.; Furuya, N.; Ishikawa, K.-I.; Imamichi, Y.; Kambe, T.; Fujimura, T.; Ueno, T.; Koike, M.; Sumiyoshi, K. Ethambutol neutralizes lysosomes and causes lysosomal zinc accumulation. Biochem. Biophys. Res. Commun. 2016, 471, 109-116. [CrossRef] [PubMed]

45. Ma, L.; Ouyang, Q.; Werthmann, G.C.; Thompson, H.M.; Morrow, E.M. Live-cell Microscopy and Fluorescence-based Measurement of Luminal pH in Intracellular Organelles. Front. Cell Dev. Biol. 2017, 5, 71. [CrossRef]

46. Anway, M.D.; Wright, W.W.; Zirkin, B.R.; Korah, N.; Mort, J.S.; Hermo, L. Expression and localization of cathepsin $\mathrm{k}$ in adult rat sertoli cells. Biol. Reprod. 2004, 70, 562-569. [CrossRef]

47. Altan, N.; Chen, Y.; Schindler, M.; Simon, S.M. Defective acidification in human breast tumor cells and implications for chemotherapy. J. Exp. Med. 1998, 187, 1583-1598. [CrossRef]

48. Papakrivos, J.; Sa, J.M.; Wellems, T.E. Functional characterization of the Plasmodium falciparum chloroquine-resistance transporter (PfCRT) in transformed Dictyostelium discoideum vesicles. PLoS ONE 2012, 7, e39569. [CrossRef] [PubMed]

49. Xu, H.; Ren, D. Lysosomal physiology. Annu. Rev. Physiol. 2015, 77, 57-80. [CrossRef] [PubMed]

50. Ben-Meir, A.; Burstein, E.; Borrego-Alvarez, A.; Chong, J.; Wong, E.; Yavorska, T.; Naranian, T.; Chi, M.; Wang, Y.; Bentov, Y. Coenzyme Q10 restores oocyte mitochondrial function and fertility during reproductive aging. Aging Cell 2015, 14, 887-895. [CrossRef] [PubMed]

51. Shults, C.W.; Oakes, D.; Kieburtz, K.; Beal, M.F.; Haas, R.; Plumb, S.; Juncos, J.L.; Nutt, J.; Shoulson, I.; Carter, J. Effects of coenzyme Q10 in early Parkinson disease: Evidence of slowing of the functional decline. Arch. Neurol. 2002, 59, 1541-1550. [CrossRef] [PubMed] 
52. Galindo, F.; Burguete, M.I.; Vigara, L.; Luis, S.V.; Kabir, N.; Gavrilovic, J.; Russell, D.A. Synthetic macrocyclic peptidomimetics as tunable $\mathrm{pH}$ probes for the fluorescence imaging of acidic organelles in live cells. Angew. Chem. Int. Ed. 2005, 44, 6504-6508. [CrossRef] [PubMed]

53. Terman, A.; Gustafsson, B.; Brunk, U.T. The lysosomal-mitochondrial axis theory of postmitotic aging and cell death. Chem. Biol. Interact. 2006, 163, 29-37. [CrossRef] [PubMed]

(C) 2020 by the authors. Licensee MDPI, Basel, Switzerland. This article is an open access article distributed under the terms and conditions of the Creative Commons Attribution (CC BY) license (http://creativecommons.org/licenses/by/4.0/). 